\title{
TELEPÜLÉSI STRATÉGIÁK A BUDAPESTI AGGLOMERÁCIÓBAN
}

\author{
(Settlement Strategies in the Budapest Agglomeration) \\ SZABÓ JULIANNA
}

Kulcsszavak:

Budapesti agglomeráció települési stratégia szuburbanizáció településfejlesztés

A budapesti agglomeráció szuburbanizációs folyamatai közepette nagy jelentőségre tesznek szert a térség településeinek elkülönülö fejlesztési stratégiái. Az elkövetkezókben ezeknek a stratégiáknak három elkülöníthetô típusát járom körbe céljaik, ideológiai hátterük, eszközrendszerük és településfejlesztési hatásaik alapján. A tipusok leírása után megkisérlem elhelyezni öket a régió terében és az 1990 utáni igazgatási, gazdasági, politikai, társadalmi folyamatok összefüggéseiben, értékelni ôket egy koherens területfejlesztéspolitika kialakításának szempontjából.

A középkori városok szabaddá tevő levegỏjére, de talán még a görög városállamok öntudatos polgári cserép-demokráciájára támaszkodó képzeteinkben a települések ma is valamiféle zárt emberi érték-, érdekközösségként jelennek meg. Bármennyire is meghaladta a településhálózat alakulása és az urbanisztikai tudás fejlödése ezt a modellt, egy erősen meghatározó terület, a közigazgatás és az önkormányzatiság struktúrája máig a fallal, de legalábbis erdövel-mezővel körülzárt település archetípusán mint alapegységen épül fel. Ennek megfelelóen a települések közigazgatási egységei a térségük gazdasági, fejlesztési, politikai, társadalmi folyamataiban mint elkủlönült aktorok vesznek részt, a kỏzigazgatási rendszertỏl és geográfiai helyzetüktöl fủggỏen több-kevesebb mozgástérrel.

A települések közötti kapcsolatok azonban ma jóval meghatározóbbak, mint a középkor városfallal kerített településeinek esetében, s a XIX. század, a modern közigazgatás-önkormányzatiság kialakulásának korszakában voltak. Különösen erỏs és sokrétủ ezeknek a gazdasági, logisztikai, kommunikációs, infrastrukturális stb. kapcsolatoknak a hálózata a világvárosok agglomerációján belül (Valér 1994). Gyakran éppen ezeknek a hálózatoknak az intenzitása, komplexitása és jó mủködése adja az adott agglomeráció különleges helyzetét, a településrendszer átlagos településeitől való minőségi elszakadást.

Budapest térsége ma az agglomerálódás erỏs jeleit mutatja, a településközi hálózatoknak sok szála kialakult, és a kilencvenes évek elején robbanásszerủen felgyorsult szuburbanizáció folyamatai tovább erősítik azokat. Az, hogy ezek a kapcsolatok hogyan alakulnak, az agglomeráció mennyire tud egységesen müködő, a szinergikus előnyöket kihasználó, ugyanakkor a hátrányokat csökkentő pályára lépni, erősen meghatározza a központi régió - az egyedüli, nemzetközileg is versenyképes magyar régió - élhetőségét, nemzetközi esélyeit. 
Az agglomeráció müködéséröl, a szuburbanizációról szóló elemzésekben és tervekben természetesen elsődleges szerepet kap a föváros, jobb esetben a térséggel együtt értelmezett föváros, a régió érdeke. Ahhoz azonban, hogy a gyakorlatban alkalmazható együttmúködési formák alakulhassanak ki, a megoldás módozatainak feltétlenül figyelembe kell venniük az agglomerációs települések elkülönült érdekeit, mozgásterét és stratégiáit. Ezek az érdekek, stratégiák ma a fơváros sokszor elemzett érdekeinél és lehetőségeinél jóval kevésbé ismertek, értékelésưk legfeljebb a föváros érdekeivel szembeállítva, erösen emocionális hozzáállással, inkább politikai, mint szakmai megnyilvánulásokban történt meg.

A budapesti agglomeráció településeinek a rendszerváltás óta eltelt években a környezet gyakori és sokszor alapvető változásaival kellett egyưtt élniưk, valamint a felgyorsuló szuburbanizációval járó, a település normál nagyságrendjét rendre meghaladó lehetöségek és veszélyek közöut kellett és kell választaniuk, egyensúlyozniuk. Stratégiaválasztásuk sikerét mindennapjaikban nem a fövárosi, regionális érdekeknek való megfelelés minösíti, hanem a település életképességének fennmaradása, a helyi lakosság megelégedettsége az elszabadult vagy megfékezett folyamatok felett, $\mathrm{s}$ mindennek politikai lecsapódása az önkormányzati választások eredményeiben.

$$
\text { * * * }
$$

Az agglomerációs településeket nem egyszerre, egyenlö intenzitással és formában érték el a szuburbanizáció hatásai. A kilencvenes évek elején még csak a lakossági kitelepedés hatásaival kellett számolni, amelyekhez gyakorlatilag csak a kilencvenes évek második felében csatlakoztak a gazdasági szuburbanizáció jelenségei. A szuburbanizáció hatásainak időbeli változásához hozzájárult a szabályozási környezet, föképpen az önkormányzati hatáskörök, az önkormányzati gazdálkodás és a telepulésrendezés rendjének gyakori és jelentös változása a kilencvenes évek folyamán. Területileg a lakossági szuburbanizáció hatókörének folyamatos növekedése figyelhetó meg, amely a telepưlések egyre nagyobb körében tette érezhetővé az immigrációs nyomást. Ugyanakkor az évtized második felében érzékelhető már a fövárostól azonos távolságra elhelyezkedö települések között kialakuló helyzeti különbség, amelyet a megközelíthetöségen és a környezeti adottságokon kívü] egyre inkább a telepủlések saját fejlesztési politikái is befolyásolnak.

Mindezektől a különbségektól eltekintve a települések általános helyzete, adottságai, illetve korlátai a rendszerváltás után az első önkormányzati testủlet megalakulása óta jellemezhetök a következö néhány legfontosabb és legáltalánosabb tényezővel:

az igazgatásban

- a település teljes körủ igazgatási, ezen belül telepưlésfejlesztési és pénzügyi önállósága;

- a telepuilési szolgáltatások kiépítéséért és múködtetéséért való felelősség; 


\section{a finanszírozásban}

- a település pénzügyi önállósága;

- a központi források elégtelensége a fejlesztési, időnként a müködtetési feladatok ellátására;

- a települési adók bevételeinek elégtelensége az adóalap alacsony volta miatt;

- a saját mobilizálható vagyon (ingatlan) csekély értéke;

\section{a településfejlesztésben}

- elmaradott infrastrukturális és intézményi szolgáltatások;

- a beépíthető ingatlanok keresletének és ennek megfelelöen árának jelentős növekedése a térségben;

- a mezőgazdaság és különösen a kertgazdaság háttérbe szorulása az ingatlanpiaci helyzetnek és a megváltozó életformának kỏszönhetően;

- a motorizáció robbanásszerü növekedése;

\section{a politikában}

- a település választópolgárainak és politikusainak ingatlantulajdonosi érdekei a föld reprivatizációja után;

- lakossági nyomás bizonyos települési szolgáltatások színvonalának kiegyenlítésére a nagyvárossal;

- a zártkerti tulajdonosok nyomása a terület beépítésre szánt övezetbe vonására, az infrastruktúra kiépítésére;

- Budapest felerösödó represszív nyomása, illetve ennek fenyegetése a szuburbanizáció megállítására, bizonyos települési szolgáltatások megvonására vagy megfizettetésére az agglomeráció településeivel szemben.

$$
\text { *** * * }
$$

A hasonló szituációval szembenéző települési stratégiák jól körülhatárolható típusokhoz közelítenek: a teljes elzárkózás, a teljes profilváltás, illetve a „laissez faire” stratégiához. Tipológiájuk elsősorban a gyakorlat felől, a település által használt településfejlesztési eszközök, a meghozott településfejlesztési döntések, az egyéb települési politikák - adópolitika, oktatáspolitika, intézményfejlesztés stb. - felől irhatók le, annak ellenére, hogy természetesen sehol sem jelenítenek meg ezek a települési döntések teljesen koherens rendszert. A mindennapi döntések által kirajzolt stratégia mögött megjelenik egy többé-kevésbé tudatosult ideológia és értékrendszer is. A település ilyetén ideológiája, értékrendszere lehet a települési identitás valódi megnyilvánulása, de pusztán politikai indulatok, lakossági, fejlesztői, tervezöi, ingatlantulajdonosi csoportérdekek álcája is. Erős települési identitás általában az elkötelezettebb ideológiákkal jár együtt, és ez a településfejlesztésben lehetővé teheti bizonyos parciális érdekek háttérbe szorítását, de az érdekek közelítésén alapuló elvszerü megoldásokat is, míg az értékmegfontolások hiánya, a települési identitás gyengesége az ad hoc, nem rendszerbe illeszkedő településfejlesztési döntéseknek kedvez. A települési stratégiák típusainak megfeleltethető a település- 
fejlesztési-rendezési lépések egy-egy rendszere, és az azokhoz kapcsolódó települési elönyök és hátrányok, amelyeknek elemzése természetesen minden felelös településfejlesztési, településrendezési folyamat elején kell, hogy álljon.

\section{Teljes elzárkózás stratégia}

Ez a stratégia a szuburbanizációs folyamatokból adódó hatások kiküszöbölésére, a település szuburbanizáció előtti méretének, népességi összetételének, funkciójának, társadalmának megörzésére irányul.

Ideológiájában elsósorban konzervatív értékek vannak jelen: a hagyományos vidéki életmód, mezőgazdasági tevékenység felértékelése; az új betelepülőkkel szembeni bizalmatlanság, sokszor ellenségesség; a jobbára alacsony színvonalon éló lakosság megóvása a pénz megjelenésétöl, és a szegény életmódhoz szükséges lehetőségek - saját kert és állattartás, olcsó bevásárlási lehetőség, tömegközlekedés - fenntartása; a helyi kultúra és hagyomány formáinak ápolása, illetve újrafelélesztése stb. (Faragó 1994). Ezek mellett azonban megjelenhetnek „modern”, a környezetvédelemből ismert értékek is, elsösorban a természetvédelem és az épített környezet védelmének köréböl, mert a környezetvédelemnek ezek a területei függenek össze leginkább a település múltjának és hagyományainak védelmével, valamint mert ezek a mindenki által jól érzékelhetó elemek képesek leginkább csoportidentitás képzésére és politikai mozgósításra.

A stratégia természetszerüen leginkább azokon a településeken jelentkezik, amelyek a nyolcvanas években az erős szuburbanizációs hatások elől településföldrajzi vagy településpolitikai okokból elzárva - megóvva - éltek, s amelyeket a kilencvenes évek nagy szuburbanizációs robbanása sokkolóan ért.

P. kis település a Pilis hegység lábánál. A tơrök utáni időkben szlovák népességgel telepítették újra, s azóta szinte településszerkezeti hagyománynak tekinthetö, hogy a közösség a szomszédos sváb település gazdasági és kulturális árnyékában létezik. A település hagyományos gazdasági tevékenysége, a Pilis mészkövének építőkővé és mésszé való feldolgozása hosszú ideig szerény, de stabil megélhetést nyújtott, amely a lakosságot a pesti felvevőpiachoz kötötte, napi kapcsolatot azonban nem jelentett. Ennek a tevékenységnek ellehetetlenülésekor a jobbára képzetlen és tőkével sem rendelkező lakosságot fokozatosan a környékbeli és a pesti ipari munkahelyek vették át, a helyi gazdaság és kereslet is szinte teljesen megszünt. A rendszerváltás utáni lehetőségek a szomszéd sváb telepưlés látványos fellendülését hozták, ami a megközelítés nehézségeivel párosulva egyrészt azt okozta, hogy P. a gazdasági fellendülésböl megint kimaradt, másrészt viszont a lakosságot a rendszerváltás súlyos társadalmi konfliktusai - munkanélküliség, elnyomorodás - sem érintették jelentősen. A szuburbanizációs sokk akkor érte a falut, amikor a kilencvenes évek elején hangsúlyosan saját gyermekeiknek készült parcellázás területén majdnem száz százalékban Budapestről kitelepülők kértek építési engedélyt. A bezárkózás stratégiáját azóta olyan következetességgel folytatja a település vezetése, hogy az agglomerációs terv készítésekor azon kevés település közé kerültek, amellyel az erösen „zöld” tendenciájú tervnek nem akadt konfliktusa. 
A bezárkózó stratégia felmerülhet azonban gyakran ott is, ahol a település jelentős, a rendszerváltás elỏtt betelepült réteggel bír, akik ezzel a stratégiával az annak idején választott települési környezet értékeit kívánják megvédeni.

T. a lakossági szuburbanizáció kedvelt szektorában elhelyezkedő kistelepülés. A rossz megközelíthetőség ellenére az elmúlt harminc évben folyamatosan történt betelepülés, egy középosztálybeli értelmiségi rétegböl, amely a helyi életmód közlekedési és infrastrukturális hátrányait a település környezeti értékeiért cserébe elviselte. A helybéli lakossággal konfliktus nem alakult ki, sőt a betelepülők nagy szerepet vállaltak a település életében, elsösorban a települési értékek védelmében. A kilencvenes évek második felében a szuburbanizáció hatóköre elérte a települést. Amikor a településrendezési tervek megújítása napirendre került, a települési önkormányzat két külterületen is lakóterületi fejlesztést irányzott elö, amely a lakosságszámot majd háromszorosára emelte volna, a ma is kritikus közúti helyzetet pedig ellehetetlenítené. A két kijelölt külterület egyike a telepulés beépített területével nem is érintkezett volna. A héttagú képviselőtestület hat tagja a kijelölt területek reprivatizált tulajdonosa, értelemszerüen „öslakos” volt. A településszerkezeti terv az önkormányzati választási kampány fỏ kérdésévé vált, ahol a múködő testülettel szemben a betelepedettek a mérsékelt és feltételekhez kötött növekedés mellett álttak ki, megszerveződtek, és a választásokon elsöprő győzelmet arattak. A testület lecserélödése várhatóan nem csak a készülö tervek megváltoztatását, de a települési stratégia văltását is eredményezi majd.

Mint láttuk, a stratégia legjellegzetesebb példái a kistelepülések között találhatók, részben, mert föleg ezek a települések tartoznak az elöbb említett szuburbanizációtól a kilencvenes évekig megmenekült települések közé, részben mert egy kislétszámú település lakossága homogénebb és szintén kis létszámú képviselötestülete jobban megengedi a stratégia által megkívánt szigorú korlátozások keresztülvitelét. Mindezekkel együtt a stratégia tiszta és következetes alkalmazása egy település politikájában ritka. Ez egyrészt a budapesti agglomeráció településeinek múltjával magyarázható, amely során a településnagyság, funkció, a település társadalma a II. világháború óta is több hullámban nagymértékben változott (Barta-BeluszkyBihari-Daróczi-Gimesi-Keresztély-Kovács-Nagy-Perger-Váradi 1999). A másik ok a föld reprivatizációja, amely különösen a kis és szegény településeken a földterületi tulajdont a gazdasági kitörés egyetlen útjává tette, és ezzel minden településen egy, a fejlesztésben erősen és közvetlenül érdekelt réteget hozott létre. Ennek a rétegnek a léte okozza, hogy fóként a kistelepulések fejlesztési stratégiája a kis létszámú önkormányzati testületek változásával - önkormányzati választásokon vagy önkormányzati választások között puccsszerü akciókban - sokszor saját ellentétébe csap át.

A stratégia eszközei jellemzően a tiltások és korlátozások köréből kerülnek ki.

A településrendezés területén a település szigorúan leállít mindenfajta új parcellázást, belterületbe yonást, sürübb beépítést stb. A volt zártkertek mezögazdasági terület-felhasználásba kerülnek. Az új építkezéseknél szigorú formai-eljárási szabályokkal óvják a települési hagyományokat. Az ingatlanpolitikában a közösségi földterületek közösségi létesítmények céljára vannak fenntartva, lakótelkek eladásánál külön eljárással kívánják a helybélieket előnyben részesíteni, gazdasági célú, spekulációs ingatlanpolitikát nem folytatnak. Új gazdasági tevékenység megtelepù- 
lésénél a döntést politikai mérlegelés előzi meg, amelyet a müszaki-környezeti szempontokon túl erősen befolyásol a település hangulata az adott beruházással kapcsolatban. Ezen a szinten elönyben részesülnek a helybéliek. A helyi adórendszer a kivethető maximális kulcsokkal dolgozik, jelentős kedvezményeket kapnak a helyi lakosok, régi helyi gazdasági tevékenységet folytatók. Az idegenforgalmat, üdülőket, ideiglenes gazdasági tevékenységet, a zártkertek településidegen lakosságát sokszor büntetőadók sújtják, a települési szolgáltatásokat velük külön megfizettetik. A település gyermekintézményeibe „külsős” gyereket nem vagy csak korlátozottan vesznek fel. A település gyermekintézményeinek megtartására törekszik akkor is, ha ez gazdaságosan és színvonalasan a létszám és a pénzügyi lehetőségek hiányában nem tartható fenn. A település életében nagy hangsúllyal szerepelnek a helyi kisközösségek, hagyományőrző kezdeményezések, amelyeket helyi részvétellel és erőforrásokkal megvalósíthatnak. Ezzel szemben a település nem törekszik külső fejlesztések és pénzeszközök bevonására: nem pályázik infrastrukturális fejlesztésekre, nem lobbizik, nem folytat külső marketing tevékenységet. A népesség ingázása az egész agglomerációban elfogadott dolog, ennek ellenére a bezárkózó településen gyakran megjelennek a kertmüvelés felélesztésének, a zártkertek ilyen funkcióban tartásának, a biogazdálkodás elterjesztésének ötletei a helyben foglalkoztatás emelésére. Szintén népszerủek a településtervezők ökoturizmussal, oktatással, kutatással kapesolatos ötletei. A bezárkózó települések kapesolatai a hasonló nagyságrendủ és helyzetủ településekre korlátozódnak, tartalmukban jellemzően kulturálisak, esetleg Budapesttel, illetve a térség nagyobb városával szembeni politikai védekezésre szolgálnak.

A bezárkózó stratégiának megfeleló településfejlesztési-településrendezési döntéseket meghozó önkormányzatoknak a következő közvetlen hatásrendszerrel kell szembenézniük (1. táblázat):

\section{TÁBLÁZAT}

A bezárkózó stratégia elönyei, hasznai, illetve hátrányai és veszélyei (Advantages, Benefits and Disadvantages, Risks of Closeting Strategy)

\begin{tabular}{|c|c|}
\hline $\begin{array}{l}\text { Elönyök, hasznok } \\
\text { nem szükséges közösségi } \\
\text { beruházás } \\
\text { a település szociológiai- } \\
\text { politikai egyensúlya várha- } \\
\text { tóan fennmarad } \\
\text { a környezeti állapotot nem } \\
\text { terhelik új veszélyek }\end{array}$ & $\begin{array}{l}\quad \text { Hátrányok, veszélyek } \\
\text { - nem bövülnek a közösségi célok- } \\
\text { ra fordítható források } \\
\text { - a település közösségi és egyéni } \\
\text { értelemben is elszegényedik } \\
\text { - nem javul a lakosok által elérhető } \\
\text { infrastruktúra és szolgáltatás szín- } \\
\text { vonala sem } \\
\text { - } \text { kiköltözés indul meg, a falu el- } \\
\text { öregszik }\end{array}$ \\
\hline
\end{tabular}

Forrás: Saját szerkesztés. 


\section{„Teljes profilváltás" stratégia}

Ez a stratégia a település felemelésére, gazdagodására, a szolgáltatási hátrányok behozására, a település képének, civilizációs színvonalának, funkciójának és népességi összetételének megváltoztatására irányul.

Ideológiájában nagy szerepet játszanak a kapitalista fogyasztói társadalom új értékei, és a településfejlesztés hagyományosan növekedésre, beruházásra ösztönző értékrendszere. A település új funkcióját a megfelelően magas szintủ lakó- és gazdasági környezet biztosításában/szolgáltatásában látja. Ennek rendelödnek alá a környezetvédelem - mint pozitiv helyi erö -, a mezőgazdaság - mint kevéssé gazdaságos, és a jó minőségü lakókörnyezetet erősen zavaró tevékenység - és minden egyéb megítélése is. A szuburbanizációt és a szabad ingatlanpiacot ezek a települések nem fenyegetésként, hanem az évtizedes elmaradottságból való kitörés lehetöségeként élik meg. Ennek megfelelően meghatározó értékei a minőség, fejlődés, növekedés, befogadás, urbánus életmód.

Ennek a stratégiának elsődleges feltétele a megfelelö tudással, akarattal és politikai elfogadottsággal rendelkező önkormányzati vezetés létrejötte. Ennek megfelelően azoknak a településeknek a köre, amelyek e stratégiát alkalmazzák, a budapesti agglomerációban elég szük, ugyanakkor rendkívül heterogén képet mutat a településnagyság és az elhelyezkedés tekintetében is. Ugyanakkor elmondható, hogy a stratégia kialakítására nagyobb esélyük van azoknak a településeknek, amelyekbe már a kilencvenes évek nagy szuburbanizációs robbanása előtti évtizedben megérkezett egy magasan képzett, viszonylag jómódú urbánus réteg, amely az eltelt idöben nem csak asszimilálódott, de helyi identitással és a településen időközben vezetö/hangadó/mintaadó szereppel is rendelkezik. Ugyancsak megfigyelhetö, hogy a stratégiát követő telepulések elsősorban a közepes méretủek közül kerülnek ki. Ezek a települések a növekedéssel a települési szolgáltatások egy új minőségi szintjére léphetnek. Nagyságuk lehetövé teszi már bizonyos saját erỏ felhasználását a fejlesztések finanszírozásában, és urbánus életmód és szolgáltatások felmutatását a településmarketing területén. Ugyanakkor kevésbé bénítja őket a politikaiideológiai széthúzás. Ez utóbbi tényezőnek a szerepe oly erös, hogy magyarázza a stratégiát alkalmazó kistelepülések bátorságát és sikereit, amelyek az elmúlt évtized agglomerációs településfejlesztéseinek legkulönösebb példái. Ugyanakkor a stratégia veszélyei a kistelepülések számára még nagyobbak, amelyek közül néhány már ez alatt a rövid idő alatt is beigazolódott.

V. a profilváltó stratégia egyik legjellegzetesebb és legtöbbet emlegetett követője. A település vezetése részben már a rendszerváltás előtt is aktív szerepet vállalt a település fejlesztésében, és azóta is egyfajta politikai-személyi folytonosság jellemzi, a stratégia megvalósításában szintén fontos szerepet játszó hivatali szakemberekkel együtt. A kilencvenes évek elején a település saját forrás, ingatlaneladás és hitelek segítségével felvásárolt az árverésre kerülő 1250 ha kárpótlási földböl mintegy 1200 hektárt. Ily módon szinte a település teljes külterülete (és mintegy 30 hektár a környező településeken) a település kezébe került, a településfejlesztés minden tekintetben 
szabaddá vált. A haszonból finanszírozható volt a település infrastrukturális lemaradásának behozása. A telepuilés akkor is az elsők között váltott, amikor a jómódú lakosság arányának növeléséböl származó buktatók nyilvánvalókká váltak: a településrendezési tervek lakófejlesztésre kijelölt övezeteit gazdasági fejlesztésekre állította át - a használati konfliktust is beszámítva -, és rövid idő alatt megteremtette ezek infrastrukturális feltételeit is. A sikerek ellenére a településen folytatott interjúban felszínre került az a kényszerhelyzet is, amelyet az annak idején felvett hitelek okoznak, és amely tulajdonképpen folyamatos ,elöremenekülésre” kényszeríti a települést.

A stratégia eszközei elsősorban offenzív, beavatkozó, a magán piaci erőket integráló politikák. A profilváltó település saját ingatlanaival aktívan vesz részt az ingatlanpiacon, saját fejlesztéseivel a legmagasabb költségvetési bevételt, az önkormányzati ingatlanérték növekedését, nagy arányú privát ingatlanpiaci befektetés mozgósítását megcélozva. A rendezési tervek a település zártkertjeit lakóterületté nyilvánítják, söt volt külterületeket is nagy részben lakóterületként és/vagy ipari területként jelölnek ki. Az építési szabályozásban a telekstruktúra, beépítési formák, közmúvesítés, közterületi kialakítás vonatkozásában mérvadóak az ingatlanpiac követelményei: az értékesítés időszakában magas áron kínálható fejlesztési területet, ,jó ingatlanpiaci árut" kell kialakítani. A területek kijelölése sokszor tudatosan veszi figyelembe a lakossági szegregáció ingatlanpiaci követelményét. A már beépült területeken külön szabályozási kedvezmények segítik a gazdasági tevékenységek, különösen a lakossági szolgáltatások megtelepedését. A település rendezési politikája liberális, rendezési terveikkel rugalmasan követik az aktuális fejlesztési igényeket, a rendezési és hatósági eljárások gyors és problémamentes lebonyolítását a magas színvonalú települési szolgáltatás részének tekintik. A lakossági és gazdasági betelepülést is minden eszközzel, teljes közmüvesítéssel, kedvezményes ingatlanárakkal, adókedvezményekkel, a települési szolgáltatások fejlesztésével mozdítják elö. Esetleges szürési feltételt csak a betelepülésre magára negatívan visszaható tényezök jelentenek: pl. egy gazdasági beruházás negatív környezeti imázsa, egy lakossági csoportnak a szegregáció piaci követelményét veszélyeztetően eltérỏ életszínvonala, ill. -módja. A település beruházás-politikáját a szolgáltatások olyan fejlesztése határozza meg, amely az urbánus életmód és a vállalkozás feltételeit megteremtik. Alapvető jelentőségü a vonalas infrastruktúrák mellett a kommunikációs rendszerek és a Budapestről való autós elérhetőség színvonala. A gyermekintézmények fejlesztésénél a mennyiségi igény kielégítése helyett minőségi, illetve speciális szolgáltatások megteremtésére törekszenek, amelyekkel ebben az értelemben nagyobb körzet kiszolgálóivá válhatnak: speciális képzéseket, egyházi, alapítványi és magán óvodákat-iskolákat fogadnak be. A település kulturális életében szintén a piaci szórakoztatási és képzési formákat részesítik előnyben. Az önkormányzati finanszírozás a rendszeres állami forrásokon túl pályázati lehetőségeket, pénzpiaci forrásokat - hiteleket -, saját ingatlanvagyonát is nagymértékben felhasználja a fejlesztések megvalósításához. A fejlesztési területek értékesítéséhez aktív marketingtevékenységet folytat. A településközi kapcsolatok a közösen megoldható/fejleszthető szolgáltatások irányában alakulnak ki, a kétoldalú előnyökön 
alapulnak. Tartalmuk a közös beruházás lebonyolítása, szolgáltatás müködtetése, a közös érdekủ beruházásért való pályázás, lobbizás, esetenként a hiányzó szolgáltatás megvásárlása.

A teljes profilváltás a településfejlesztésben nagy lehetőségeket, ugyanakkor nagy veszélyeket is rejt (2. ábra):

\section{TÁBLÁZAT}

A „teljes profilváltás" stratégia elönyei, hasznai, illetve hátrányai és veszélyei (Advantages, Benefits and Disadvantages, "Overall Profile Change" Strategy)

\begin{tabular}{|c|c|}
\hline $\begin{array}{l}\quad \text { Elönyök, hasznok } \\
\text { - } \text { a település új profilt kaphat } \\
\text { - } \text { nagyságrendileg megnöveked- } \\
\text { hetnek az önkormányzat forrásai } \\
\text { - } \text { az elöregedési, elszegényedési } \\
\text { folyamatok megállíthatók } \\
\text { - a megnövekedett forrásokból a } \\
\text { régi településrész is növekedhet }\end{array}$ & $\begin{array}{l}\text { Hátrányok, veszélyek } \\
\text { _ } \quad \text { komoly önkormányzati szerep- } \\
\text { vállalás szükséges a szervezés- } \\
\text { ben, sokszor a finanszírozásban is } \\
\text { - } \text { rossz gazdasági tervezés, marke- } \\
\text { ting esetén a projekt befulladhat, } \\
\text { a település eladósodhat } \\
\text { - a település politikai egyensúlya } \\
\text { felborulhat a „gyüttmentek” javára } \\
\text { - új környezeti problémák jelen- } \\
\text { hetnek meg } \\
\text { - alvóvárossá válhat a település }\end{array}$ \\
\hline
\end{tabular}

Forrás: Saját szerkesztés.

\section{„Laissez faire” stratégia}

Ennek a stratégiának elsödleges célja a település törvényben meghatározott kötelességeinek teljesítése a pénzügyi egyensúly fenntartása, esetleg a pénzügyi pozíció javítása mellett.

Bár tudatos ideológia általában sokkal kevésbé határozza meg, mint az elözö két települési stratégiát, hátterében felfedezhetỏ a településtervezés-rendezés-fejlesztés értelmének és hasznosságának megkérdőjelezése, és a települési önkormányzat aktív piaci szerepének, eszközeinek elutasítása. A telepưlési önkormányzat ebben az esetben önmagát a törvényben reá származtatott állami szolgáltatások biztosítójának tekinti, a szuburbanizációt pedig hatásaival együtt a környezet olyan változásaként értelmezi, amelyhez alkalmazkodva neki ezeket a szolgáltatásokat fenn kell tartani. Ebböl adódóan a stratégia értékei nem a településfejlesztéshez, hanem az adminisztratív működéshez kapcsolódnak: be nem avatkozás, gördülékenység, problémamentesség, konfliktuskerülés.

Ez a stratégia a legelterjedtebb települési stratégia a budapesti agglomerációban. Elterjedtsége csak részben tekinthetô az átmenet - a szabályozás változékonysága, az önkormányzati testületek és apparátusok felkészületlensége - eredményének. Kialakulásában fontos szerepe volt a településfejlesztés és -rendezés hagyományos és beidegzett gyakorlatának, tehetetlenségének az újonnan fellépő - sokszor profiljában, 
nagyságában, módszereiben is ismeretlen - magán fejlesztési akarattal szemben. Ennek megfelelően különösen azok a települések léptek erre a pályára, amelyeknek településképét, közösségét, identitását már a szuburbanizáció beindulása elött a hatvanas-hetvenes évek szocialista várostervezése nagy arányú ipari és lakástelepítésekkel rombolta.

Sz. lázasan készíti az 1994-es általános rendezési tervének módosítását. A településen a gyermekintézmények helyzete a bỏvítések ellenére kritikus, minden évben felvételi kérelmeket kell elutasítani. Ugyancsak kritikus a település úthálózatának és a Budapestre vezetö tömegközlekedési vonalaknak terhelése is. Az önkormányzat tudatában van a helyzetnek, a lakóterületi fejlesztéseket lassítani szeretnék, ennek ellenére a készuillö településrendezési terv újabb lakóterületeket jelöl ki, amelyek beépülésével a lakosság további 70\%-kal növekedhet, olyan területen, ahol az intézményellátás a mai intézmények bővítésével sem megoldható. Az agglomerációs tervben zöldövezetnek szánt terület is lakóterületté válik, egyes helyeken már a beépités is megkezdődőtt. Szintén növelendỏ a gazdasági tevékenységek, ipari parkok területe, amely gyakorlatilag a tervezett M0-s autóút települést érintő szakasza teljes hosszát követi. A település iparủzési adóból származó bevétele 2001-ben 262 millió forint volt, 2002-re 450 milliót terveznek. A településrendezési tervek jellemzỏen csak az érintett, átsorolandó területekre készülnek.

Ezeken a településeken a csorbított települési értékek mellett a lakossági, tulajdonosi érdekeknek olyan heterogenitása jött létre - a lakásprivatizáció és a föld reprivatizációja adott esetben ezt tovább fokozta -, amely mellett konzekvens településfejlesztési koncepció végigvitele lehetetlennek tünik. Legerősebb nyomásként ebbe az irányba mégis a települési önkormányzatok alulfinanszírozása hat. Az alulfinanszírozást pedig azok a települések élték meg a rendszerváltás után a legélesebben, ahol egy, az agglomerációhoz mérten urbánus intézményhálózatot egy lassan elszegényedő lakosság mellett kellett fenntartani. Ezeken a településeken természetes módon vált a költségvetés egyensúlyának fenntartása elsődleges szemponttá, bármiféle személyi jövedelemadót vagy iparủzési adót emelô fejlesztés szívesen látottá.

A ,laissez faire" stratégia eszközei a település hagyományos, nem piaci eszközei, a szabályozási szerep tartalmi részének minimumra csökkentésével.

A település a nyomás alapján lakó- vagy üdülóterületté nyilvánítja a volt zártkerteket, külterületeken új lakó- és gazdasági fejlesztési területeket jelöl ki, amennyiben a terület ellátottsága, infrastruktúrája formálisan megfelel az önkormányzat ellátási kötelezettségeinek. A területek kijelölésénél a településszerkezet összefüggései kevéssé játszanak szerepet a fejlesztô szempontjaival szemben. Így gyakori, hogy ez a településrendezési politika az egymással összehangolatlan fejlesztési projektek eredményeként széttöredezett, mozaikos településszerkezetet hoz létre. A település rendezési politikája az elöző stratégiához hasonlóan liberális, célja azonban nem a szolgáltatás magas szintje, hanem az önkormányzati bevételek maximalizálása, a kiadások minimalizálása ếs a konfliktusok elkerülése. A település a területek parcellázásában, infrastrukturális előkészítésében nem vállal szerepet, viszont kifejlett jogi-technikai megoldásokat alkalmaz arra, hogy a fejlesztésekhez kapcsolódóan szükségessé váló települési beruházásokat a fejlesztővel megfinanszíroztassa, 
felépíttesse. Az önkormányzati beruházás-politikát a törvényben előirt szolgáltatások mennyiségi kielégítése és a lakossági-fejlesztỏi akarat nyomásának nagysága határozza meg, összevetve a megoldás finanszírozási lehetőségeivel. A közösségi beruházások finanszírozásában, így azok helyének, profiljának, mikéntjének befolyásolásában is döntő szereppel bírnak magánfejlesztők, illetve az éppen aktuális regionális-kormányzati pályázati lehetőségek. A település adópolitikájában minden lehetséges helyi adót alkalmaz, az adókulcsot a hasonló helyzetü települések adóversenye határozza meg, a kedvezmények nagyrészt általánosak, és ahhoz kapcsolódnak, hogy az adott beruházás milyen kötelező települési fejlesztéseket vállal át. A település aktív ingatlanpolitikát nem folytat, de a fejlesztésekbe eső saját ingatlanait a települési intézmények elhelyezésére, illetve az önkormányzati bevételek növelésére felhasználja. A település oktatási politikáját a kötelező minimum határozza meg, az intézmények müködtetési költségeinek minimalizálása a helyzettől függően időnként olyan politikainak tủnő döntéseket is magával hoz, mint a külsős gyerekek kitiltása, vagy a szomszédos kerülettel-településsel való együttmüködés. A település településközi kapcsolatait föként a hasonló települések közötti versenyhelyzet, a nagy versenytárs, Budapest elleni közös politikai fellépés, és az esetenkénti közös intézmény- vagy szolgáltatásfinanszírozás határozza meg.

A „laissez faire” stratégia településfejlesztési-településrendezési hatásainál lényeges az előnyök és hátrányok hatókörének és időtávjának különbözösége. A döntöen rövid távú, politikai és finanszírozási előnyőkkel hosszú távú környezeti, településszerkezeti és társadalmi hátrányok állnak szemben (3. táblázat):

\section{TÁBLÁZAT}

A ,laissez faire” stratégia elönyei, hasznai, illetve hátrányai és veszélyei (Advantages, Benefits and Disadvantages, "laissezfaire" Strategy)

\begin{tabular}{l|l}
\hline \multicolumn{1}{c|}{ Elönyök, hasznok } & \multicolumn{1}{c}{ Hátrányok, veszélyek } \\
- csökken a testületre nehezedỏ poli- & - nönek a környezeti ártalmak \\
tikai nyomás & - az új területek infrastruktúrája \\
- a stratégia minimális közösségi & központi irányítás nélkül nagyon \\
beruházást igényel & nehezen alakítható ki, időnként \\
& teljes patthelyzet áll eló, ami visz- \\
& szahathat a régebbi településré- \\
& szekre is \\
& $-\quad$ nem irányítható a betelepülök \\
& szociológiai összetétele, ami új \\
& terheket róhat az önkormányzatra \\
\hline
\end{tabular}

Forrás: Saját szerkesztés.

Az egyes települések stratégiái természetesen nem felelnek meg teljes mértékben a fenti három stratégia valamelyikének. Még abban az esetben is, amikor a település határozottan elkötelezett valamely irányban, konkrét kérdésekben, a politikaipénzügyi helyzet függvényében máshogyan dönthet. A települések fejlesztési stratégiái ritkán nyernek explicit formát - az OTÉK által elöírt településfejlesztési 
koncepciónak pedig ezt legalábbis részben tartalmaznia kellene --, a települések rendszerezése tehát leginkább múködési rendszerük, döntéseik alapján lehetséges. (Ebböl a szempontból érdekes lenne a településfejlesztési stratégiák explicit formáit, azaz a településfejlesztési koncepciókat és polgármesteri választási programokat a települések későbbi fejlesztési- és rendezési döntéseivel összevetni.) Annak ellenére, hogy a települések lehatárolása így rendkívül önkényesnek és képlékenynek hat, mára viszonylag egyszerủ statisztikai adatokkal megragadható az egyes stratégiákat jellegzetesen követők csoportja (4. táblázat):

\section{TÁBLÁZAT}

A budapesti lakossági szuburbanizáció által leginkább érintett települések köre (Settlements are Principally Affected by Budapest Suburbanisation)

\begin{tabular}{|c|c|c|c|}
\hline Település & $\begin{array}{c}\text { Budapeströl } \\
\text { évente állandó } \\
\text { státusszal beköl- } \\
\text { tözók átlagos } \\
\text { száma } \\
\text { (1997-2000) }\end{array}$ & Település & $\begin{array}{l}\text { Budapeströl } \\
\text { évente állandó } \\
\text { státusszal bekôl- } \\
\text { tözók átlagos } \\
\text { száma ezer la- } \\
\text { kosra vetítve } \\
\text { (1997-2000) }\end{array}$ \\
\hline Érd & 1724 & Telki & 83,6 \\
\hline Budaörs & 734 & Leányfalu & 61,5 \\
\hline Gyál & 705 & Budajenő & 60,0 \\
\hline Dunakeszi & 675 & Veresegyház & 58,0 \\
\hline Szigetszentmiklós & 674 & Diósd & 56,3 \\
\hline Szentendre & 610 & Erdökertes & 56,2 \\
\hline Szigethalom & 540 & Nagykovácsi & 56,0 \\
\hline Veresegyház & 535 & Szigetmonostor & 52,0 \\
\hline Fót & 502 & Szigethalom & 44,6 \\
\hline Budakeszi & 416 & Pilisborosjenő & 43,9 \\
\hline
\end{tabular}

Forrás: Városkutatás Kft.

Látható, hogy a kilencvenes évtized végének legnagyobb abszolút lakossági immigrációinak listáját az alapvetöen a „laissez faire”, míg a legnagyobb relatív immigrációk listáját a „teljes profilváltás” stratégiát követő települések vezetik. A sikeres bezárkózó stratégiát követők természetesen mindkét listának az alján helyezkednek el.

A stratégiaválasztásnak természetesen a település adottságaihoz és a közösség akaratához kell igazodnia ahhoz, hogy bármely stratégia is sikeresen, a hátrányok minimalizálásával megvalósítható legyen. Bár nem tehető egyenlőségjel a három jellegzetes stratégia közé, mindháromról elmondható, hogy saját értékrendszerén belül is csak a települési döntések koherenciájával érhet el eredményt: a település saját szerepvállalásának arányában képes kézben tartani fejlődésének folyamatait. A településfejlesztés településrendezésen kívül eső eszközei - a helyi adók rendszere, a saját ingatlanpolitika, a közmủ- és intézményfejlesztés prioritásai, a városmarketing stb. - ma azonban még csak a legritkább esetben integrálódnak tudatosan 
valamiféle településfejlesztési koncepcióba. Az ezeken a területeken meghozott települési döntéseket igen gyakran szük pénzügyi, müszaki, politikai szempontok uralják, és inkább csak magában a településrendezési döntések rendszerében érhető tetten a választott stratégia.

$$
* * *
$$

Az agglomerációs települések stratégiáit az elmúlt bő évtized folyamán több tényezö változása is befolyásolta, módosította. Egyik oldalról a települési önkormányzatok mozgásterének bővülése a rendszerváltozás utáni jogalkotási folyamattal fokozatosan, több év leforgása alatt történt, amelynek föbb állomásai az önkormányzati törvény és a településrendezésrő̉ szóló törvény, valamint ezek folyamatos módosításai és a hozzájuk tartozó kiegészítỏ kormány- és miniszteri rendeletek voltak. Több évet vett igénybe a települések jelentős részben megújult politikai vezetése számára a szükséges igazgatási, jogi, településfejlesztési, piaci ismeretek megszerzése is. Ezeknek a feltételeknek lassú kialakulása különösen a "teljes profilváltás" stratégiájának alkalmazását és elterjedését akadályozta a kilencvenes évek első felében.

Jelentős változást okoztak magának a fövárosi szuburbanizációs folyamatnak idöbeli és térbeli változásai is (Gábor 2001). A kilencvenes évek közepén felgyorsuló lakossági kitelepülés olyan agglomerációs településeket tett a szuburbanizáció célterïletévé, amelyeket a korábbi hullámok elkerültek. Elsősorban az agglome-rálódás sugarának megnövekedéséröl van szó, illetve az időközben megépült autópálya- és gyorsforgalmi útszakaszok mentén kiterjedő vonzási területröl. Ugyanakkor megfigyelhető a célterületek szektoriális változása is, hiszen az évtized közepén egyértelmủen meghatározó nyugat-északnyugati szektor mellett az évtized végére megerősödni látszik a klasszikus mintájú kivándorlásban a déli és az északi-északkeleti szektor, a szegénységi kivándorlásban pedig a délkeleti szektor szerepe. A lakossági kiáramlás célterületeinek megváltozásához adódik a kilencvenes évek közepétöl megjelenő nagyobb arányú gazdasági fejlesztés az agglomerációban, ami még inkább kötödik a nagy kapacitású közúti tengelyekhez (Tosics-Gerőházi-Szabó 2002).

A legélesebb változást azonban az agglomerációs települési stratégiákban mindenféleképpen a települési önkormányzatok finanszírozási rendszerének időbeli változása hozta, amely a helyben képzödő személyi jövedelemadónak a település bevételeiben kezdetben nagy, később egyre csökkenö jelentősége mellett, megadta a lehetöséget a saját, a gazdasági forgalom nagyságán alapuló iparúzési adó kivetésére. A kilencvenes évek folyamán így a jómódú népesség vonzásának jelentỏsége egyre csőkkent, míg az iparüzési adó szerepe a gazdasági fellendüléssel és a kiépülő autópályák mellett megtelepedett nagy forgalmú gazdasági tevékenységekkel (főként kereskedelem) egyre nött. A települési önkormányzatok kialakulásakor főleg azok a települések koncentráltak a jómódúak letelepedésének ösztönzésére, amelyek már a nyolcvanas években a kiköltözők vagy az elit üdülőfunkciók célterületei voltak. A költségvetés bevételi arányainak változása aztán lehetőség szerint 
a településrendezési tervekben rögzített funkciók gyors változását vonta maga után, nem minden városszerkezeti konfliktus nélkül. Ahol a gyors lakó-gazdasági funkcióváltás helyhiány miatt lehetetlen volt, az időközben felépített intézmények müködtetése, az újonnan jöttek infrastrukturális igényei a települési költségvetés komoly krízisét okozták.

$$
* * *
$$

Ha az agglomerációs települések kialakult településfejlesztési stratégiái intenzitásukban és módszereikben nem is, értékválasztásukban inkább állandónak bizonyulnak. Ez a viszonylagos stabilitás részben a politikai stabilitáshoz kötődik - az agglomerációs településeken, különösen a kistelepüléseken gyakori a polgármesterek, képviselötestületek több cikluson át tartó müködése -, részben pedig a stratégiaváltás nehézségeit takarja. Akár bezárkózó, akár profilváltó, akár , laissez faire” stratégiát folytat egy település, a meghozott döntések még sok éven át befolyásolják a további lehetőségeket: megadott építési jogokat és adókedvezményeket nem lehet visszavonni, a nagy léptékủ településrendezési tervek megváltoztatása pénz- és időigényes, a hiteleket fizetni, a felépített intézményeket működtetni kell, ugyanakkor elszalasztott fejlesztési, pályázati lehetőségeket általában nem lehet pótolni. Ezek miatt különösen nehéz egy település pályáját valamelyik fejlesztésre orientáló stratégiából a bezárkózó, konzervatív irányba terelni. Bár politikai értelemben idöröl időre akadnak az agglomerációban éles stratégiaváltási kísérletek, amelyek valamely stratégia látványos túlkapásához, kudarcához kapcsolódnak, ezeket az éles váltásokat a hosszú távú elkötelezettségek általában tompítják.

A stratégiák ilyen állandósága az agglomeráció térképén a szerepek állandóságát eredményezi. Ezen a térképen ma határozott többségben a „laissez faire” stratégiát követök, kisebb arányban a profilváltó, illetve a bezárkózó települések vannak. A főváros szuburbanizációt fékezni kívánó településfejlesztési kívánalmaival természetesen leginkább a két elöbbi stratégiát követő települések állnak ma is konfliktusban. A konfliktus gyökere azonban részben éppen az, hogy a központi településés infrastruktúra-fejlesztési döntések kevéssé veszik figyelembe az agglomerációs települések fejlesztési stratégiáit.

A települési akaratok eloszlása ugyanis nem fedi a településrendezés, -fejlesztés hagyományos vizsgálati módszerei alapján létrejött térképet és ebböl származtatott tervet, ahol a fejlesztési lehetöségek nem a települések saját akarata, hanem valamiféle központi akarat, a településhálózat fejlesztési elvei alapján oszlanak meg. (Erre a módszerre jó példa a Budapesti Agglomeráció Területrendezési Terve, bár ennek a tervnek az elkészülte már jónéhány konzultatív elemet tartalmazott, amely az agglomerációs települések stratégiadöntéseit részben integrálni tudta.) Ezekben a tervekben fejlesztési lehetőséget általában a már bizonyos nagyságot és fejlettséget elért települések kapnak, azok közül is a magtelepüléstöl elég távol esök, hogy a településhálózat réteges csillagszerkezete fennmaradjon/kialakuljon. A Christaller- 
Tér és Társadalom 17. évf. 2003/4. 101-116. p.

féle modell viszont korántsem esik egybe a nagyvárosok agglomerációjában a spontán lakossági migráció és a magán gazdasági fejlesztések megtelepedési mintájával, amely inkább a városfejlődés gyürüs, tengelyes, szektoros modelljeihez hasonlóan írható le. A két minta egymástól eltéró szerkezete önmagában hordozza a konfliktust: a közelségük vagy méretük alapján nem fejlesztendő települések úgy érzik, hogy a kitörés, a felzárkózás lehetöségét vonják meg tőlük, az „ellenpólusok” fejlesztése pedig egy milliós metropolisz közelében mindig is pénzrabló és eredményết tekintve kétséges vállalkozásnak bizonyult a várostervezés története folyamán.

A saját települési stratégiák konfliktusai azt példázzák, hogy a mai önkormányzati, településrendezési, finanszírozási rendszer lehetővé teszi - bizonyos értelemben ki is kényszeríti - a kis települések hatékony ellenállását a fővárosi, régiós akaratnak, a szakma általánosan elfogadott értékeinek. Kérdéses, hogy a konfliktusok megoldása mi legyen. A szakma által elvárt felsöbb (terület)rendező erő - az agglomerációs területrendezési terv törvényi elfogadása, a régió terveinek kötelezővé tétele stb. - már ma is csak korlátozott eredményt érhetne el a településrendezési tervek elörehaladott állapota miatt. Az agglomerációs települések egyéni stratégiái a rendszerváltás óta eltelt időszakban tehát az átmeneti korszak minden nehézsége ellenére olyan újfajta településalakító tényezővé váltak, amellyel minden új - és éppen emiatt remélhetőleg újfajta - területtervezésnek számolnia kell. Megoldás, konfliktuskezelés elsősorban nem is a területi és településtervezés hierarchiájának óhajtott visszaállításától, hanem a települések stratégiaalakítását inkább befolyásoló tényezók: a települési szolgáltatások központi finanszírozásának, a települési adóknak és a támogatási rendszereknek egymással és a területrendezés érdekeivel való finomabb összehangolásától várható.

A szuburbanizációs folyamatok változása, a térszerkezet átalakulása ma magában is olyan környezeti feltételeket teremtenek, amelyek a szabályozási környezet változása nélkül - vagy ha tetszik, az elött - a települési stratégiák hangsúlyainak, irányainak, jelentőségének módosulását okozzák.

A lakossági migráció nagyságának alakulása a budapesti agglomerációban arra enged következtetni, hogy a szuburbanizáció robbanásszerú növekedése, amely a kilencvenes évek második felét jellemezte, napjainkban lelassul. Ha ez a tendencia folytatódik, a mai szinten jelentős kiáramlás fennmaradása esetén sem várható, hogy az agglomeráció településrendezési terveiben megjelenő fejlesztési területek akár csak nagy részükben is beteljenek. A fejlesztési források szükülésével jelentösebbé válik a ma még lényegtelennek tủnỏ különbség a profilváltó és a „laissez faire" stratégiát követỏ települések között. Szintén egyre fontosabbá válhat a lakossági és gazdasági migráció céltelepülésének szétválása, egyes települések egyre határozottabb profilja e tekintetben is. A motorizáció további növekedése miatt a települések helyzetében és stratégiaválasztásában egyre jelentösebbé válik a nagy 
kapacitású közlekedési folyosók, esetleg tömegközlekedési tengelyek menti elhelyezkedés. Hosszabb távon feltételezhetö a bezárkózó települések számának további csökkenése. Ezek a települések környezeti adottságaiknak megfelelöen általában mind jó minôségü lakóterületnek, mind rekreációs funkcióknak, esetleg a kutatástfejlesztést koncentráló kis szilícium-völgyeknek alkalmasak. Az addig elhalasztott fejlesztési lépések azonban a szegénységi szegregáció célterületévé is tehetik őket. Szintén csökkenni fog a fejlesztési verseny erösödése miatt a ,laissez faire" stratégiát folytatók száma, stratégiaváltásukat, profiltisztításukat azonban nehezíti az időközbeni ad hoc telepuilésfejlesztési döntések káros öröksége.

Összességében elmondható: a budapesti agglomerációban nem következik be a településszerkezet olyan mértékü amerikai típusú átrendeződése, mint amelyet a településrendezési tervek ma előrevetítenek. A kilencvenes évek minden tekintetben átmeneti korszakának hosszú távon ható, nehezen kezelhető urbanisztikai öröksége nem az intenzív profilváltást végbevivỏ településeken, hanem a szegénységi szuburbanizáció célterületein és a „laissez faire” stratégiából szabadulni nem tudó települések károsodott struktúrájában marad ránk.

\section{Irodalom}

Barta Gy.-Beluszky P.-Bihari Zs.-Daróczi E.-Gimesi J.-Keresztély K.-Kovács K.-Nagy S.Gy.-Perger É.Váradi M.M. (1999) Társadalmi-gazdasági átalakulás a budapesti agglomerációban. Regionális Kutatási Alapítvány, Budapest.

Faragó L. (1994) „A kicsi szép, de gyenge is” Neopopulista területfejlesztési stratégiák reneszánsza. Falu Város Régió. 24-25. o.

Gábor P. (2001) Népességváltozás Magyarországon az 1990-es években: a szuburbanizáció kezdete? Falu Város Régió. 9-10. o.

Tosics I.-Gerőházi É.-Szabó J. (2002) A szuburbanizáció jelensége és a budapesti agglomeráció. Városkutatás Kft, Budapest.

Valér É. (1994) Az agglomerálódást kifejezỏ tényezök idóbeli változása. - Falu Város Régió, 6-7. 34-36. o. 